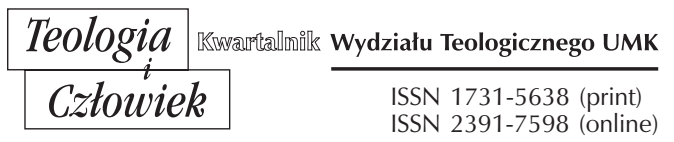

(ब) $(\oplus \Theta$

44(2018)4, ss. $165-170$

KS. MICHAŁ SADOWSKI

WYDZIAL TEOLOGICZNY UNIWERSYTETU MIKOŁAJA KOPERNIKA W TORUNIU

MICHALSADOWSKI@UMK.PL

ORCID 0000-0003-4562-977X

\title{
SPRAWOZDANIE Z MIĘDZYNARODOWEJ KONFERENCJI NAUKOWEJ „CHRZEŚCIJAŃSKI ORIENT: HISTORIA, DZIEDZICTWO, WSPÓłCZESNOŚĆ"
}

DOI: http://dx.doi.org/10.12775/TiCz.2018.044

W dniach 15-16 maja 2018 na Wydziale Teologicznym UMK odbyła się międzynarodowa konferencja naukowa organizowana przez Katedrę Historii Kościoła i Patrologii. Prelegenci przedstawiali zagadnienia związane z chrześcijańskim Orientem, które w szczególności dotyczyły Kościołów tradycji syryjskiej, arabskiej, koptyjskiej oraz etiopskiej. Konferencję otworzył ks. prof. dr hab. Dariusz Zagórski, kierownik Katedry Historii Kościoła i Patrologii. Zorganizowane przedsięwzięcie było prawdopodobnie pierwszym tego typu wydarzeniem o charakterze naukowym w kraju, na którym poruszane były zagadnienia o tak szerokim zakresie językowym, kulturowym i teologicznym w kontekście mozaiki chrześcijańskiego Orientu. Zainteresowanie zaproponowaną problematyką dało wyraz we frekwencji przybyłych uczestników oraz dyskusjach podsumowujących poszczególne bloki konferencji.

Jako pierwszy głos zabrał gość z Niemiec, Andreas Ellwart, pracownik Uniwersytetu w Hamburgu. Problematyka prelekcji zatytułowanej „Lexicography in the Semitic Languages of Eastern Christianity: Challenges and Solutions” dotyczyła prezentacji historii leksykografii języków 
semickich używanych w różnych wspólnotach chrześcijańskiego Orientu. Badacz w swym wystąpieniu przywołał takie dzieła, jak: Syrorum Peculum Andreasa Masiusa (1571), Lexicon syriacum Christophorusa Crinesiusa (1612), Lexicon Aethiopicum Jacoba Wemmersa (1638), Lexicon Aethiopico-Latinum (1661) oraz Commentarius (1691) Hioba Ludolfa, Lexicon Heptaglotton Edmunda Castella (1669). Nie zabrakło także informacji o nieocenionych pomocy współczesnych badaczy literatury syryjskiej, takich jak: Lexicon Syriacum Carla Brockelmanna (1895) oraz A Syriac Lexicon Michaela Sokoloffa (2009).

Referat ukazujący historię chrześcijaństwa w Indiach przygotował ks. prof. dr Jacob Thekeparampill, dyrektor Ekumenicznego B adawczego Instytutu Św. Efrema (SEERI, Kottayam, Indie). Wykład zatytułowany „India as the Land of Syriac and Oriental Christianity” został wygłoszony przez ks. dr. Mateusza Rafała Potocznego. W wygłosie zwrócono uwage na syryjskie pochodzenie indyjskiego chrześcijaństwa, którego wyznawców możemy spotkać głównie we współczesnym stanie Kerala. Prelegent wskazał na jego starożyte pochodzenie tamtejszego Kościoła, bo według tradycji, sięgające czasów apostolskich (św. Tomasz Apostoł) oraz zapoznał uczestników konferencji z zachowaną architekturą chrześcijańską oraz tradycjami liturgicznymi.

Pani mgr Dominika Kovačević z Wydziału Orientalistycznego Uniwersytetu Warszawskiego wygłosiła referat pt. „Liturgiczne i ludowe tradycje arabskiego prawosławia dzisiaj”. Prelegentka wskazała, że prawosławni Arabowie i Aramejczycy wnieśli istotny wkład w ryt bizantyjski na przestrzeni dziejów, jednocześnie ulegając wpływom zewnętrznym, zwłaszcza greckim, a później także zachodnioeuropejskim. W wyniku tej mieszanki zarówno w sferze liturgiki, jak i folkloru, powstały pewne charakterystyczne zwyczaje i obrzędy, a z racji zasady autokefaliczności czyli niezależności- poszczególnych prawosławnych Kościołów lokalnych, zachowanie tej specyfiki było możliwe.

Ks. dr Mateusz Rafał Potoczny z Wydziału Teologicznego Uniwersytetu Opolskiego przybliżył problematykę z zakresu chrześcijaństwa syryjskiego. W przedłożonym referacie „Misterium (taksā) chrzcielne w liturgii Asyryjskiego Kościoła Wschodu” prelegent odniósł się do taksā chrzcielnego w liturgicznej tradycji Asyryjskiego Kościoła Wschodu, który w pierwszym tysiącleciu chrześcijaństwa był jednym z najprężniej rozwi- 
jających się Kościołów, a dziś stanowi najmniejsze ogniwo starożytnych wspólnot chrześcijańskich. Punktem wyjścia podjętej refleksji była grupa najstarszych źródeł patrystycznych ukazujących etapy rozwoju obrzędu oraz związana $\mathrm{z}$ nim teologia.

W drugim dniu konferencji, jako pierwszy zabrał głos prof. Martin Tamcke z Uniwersytetu w Getyndze. Przedłożył on referat „«In my Love for Humanity I Have Based my Life on Yours». Meditation on Ideals in the Legend MS Cambridge 2818". W swym wystąpieniu profesor Martin Tamcke omówił manuskrypt Cambridge 2818, zawierający biografię asyryjskiego katolikosa Išo’yahba III, napisanego przez jego ucznia i następcę, Hnanišo.

Przybyły z Malty ks. prof. John A. Berry, wykładowca Uniwersytetu Maltańskiego, wygłosił referat pt. „Resilient Faith: Theological Aspects of the Church in the Middle East”. Profesor Berry zauważył w swym referacie, że choć wizja „Kościoła światowego” została podjęta przez Vaticanum II, to jednak można dostrzec swoisty partykularyzm w kontekście Kościołów bliskowschodnich $\mathrm{z}$ racji na multireligijne tło oraz kryzys o charakterze politycznym. Także pod względem różnorodności liturgicznej i teologicznej, Kościół lokalny wydaje się rozdrobniony i podzielony. W swoim wystąpieniu prelegent zadał ważne pytanie o tożsamość Kościoła na Bliskim Wschodzie, szczególnie w tak niestabilnym kontekście społeczno-politycznym?

Ojciec dr Andrij Oliynyk z Ukraińskiego Uniwersytetu Katolickiego we Lwowie (Ukraina) wygłosił referat pt. „Ambona jako środek promocji wartości chrześcijańskich w społeczno-politycznych życiu Antiochii Syryjskiej: doświadczenie pastoralne św. Jana Chryzostoma (349-407)”. Prelegent zwrócił uwagę, na działalność św. Jana Chryzostoma w Antiochii w latach 386-398, które można nazwać okresem stopniowego oraz praktycznego doskonalenia umiejętności homiletycznych późniejszego Patriarchy Konstantynopola.

Pani mgr-lic. Marzanna Klepacka z Wydziału Teologicznego Uniwersytetu Mikołaja Kopernika w Toruniu podjęła się charakterystyki chrześcijaństwa egipskiego w referacie zatytułowanym „Egipscy chrześcijanie - Koptowie, spadkobiercy św. Marka i ich liturgia”. Prelegentka ukazała historię Kościoła Koptyjskiego, należącego do najstarszych społeczności chrześcijańskich na świecie, bo sięgającej według tradycji działalności św. Marka Ewangelisty. 
Została także podjęta tematyka z zakresu liturgii, która jest wyrazem inkulturacji wydarzeń zbawczych $\mathrm{w}$ realia egipskie, sprawowanie sakramentów, budownictwo sakralne, a także obyczajowość religijna Koptów.

Profesor Michael Abdalla z Uniwersytetu Adama Mickiewicza w Poznaniu przedłożył referat zatytułowany „Antiochia i Aleksandria. Z dziejów relacji apostolskich Kościołów syryjskiego i koptyjskiego”. Autor ukazał w swym referacie głęboką więź łączącą oba Kościoły, Antiocheński Kościół Syriacko-Ortodoksyjny i Kościół Koptyjski (aleksandryjski), które zachowując niezależność w pełni uznają nawzajem wszystkie sakramenty oraz doktryny teologiczne. Ważnym elementem jedności obu Kościołów jest fakt, że w okresie okrutnych prześladowań ze strony Bizancjum, kiedy samo istnienie Kościoła Antiocheńskiego było zagrożone, ks. Jakub Baradeusz został wyświęcony na biskupa przez patriarchę koptyjskiego Teodozjusza. Według profesora Abdalli, niektórzy badacze wskazują także na wspólne elementy muzyki kościelnej obu tradycji sugerując jej syryjskie pochodzenie.

W przestrzeni tradycji syryjskiej uczestnicy konferencji mogli pozostać dłużej dzięki wykładowi prof. inż. Mirosława Ruckiego z Uniwersytetu Technologiczno-Humanistycznego w Radomiu, który przedłożył referat pt. „Iluzje polityczne stwarzane przez misjonarzy w Hakkari (na podstawie relacji R. Termena)". Prelegent ukazał problem o charakterze religijno-politycznym ostatnich dziesięcioleci a dotyczący istnienia wspólnot chrześcijańskich w regionie Hakkari południowo-wschodniej Turcji przed ich totalną zagładą. Źródłem wystąpienia był raport rosyjskiego generała Termena Ryszarda, który w latach 1901-1908 służył na Kaukazie i był wicekonsulem w wilajecie Wan. Jak zauważono, znaczną część tego raportu stanowią opisy działalności misjonarzy rosyjskich (reprezentujących Kościół prawosławny), francuskich (Kościół katolicki), angielskich (Kościół anglikański) i amerykańskich (Kościoły protestanckie) wśród chrześcijańskiej ludności asyryjskiej regionu Hakkari.

Zagadnienie obecności wspólnot etiopskich w Jerozolimie zreferował o. dr hab. Mieczysław Paczkowski z Wydziału Teologicznego UMK. Prelegent nawiązując do bogatej historii starożytnej cywilizacji etiopskiej wskazał na jej bogatą spuściznę kulturową, która w sposób nierozłączny jest związana z tradycją chrześcijańską. Obecność ciemnoskórych Etiopów w Jerozolimie jest poświadczona w źródłach pisanych przynajmniej od 
XII w. Prelegent wskazał także na problemy i ich genezę, z jakimi boryka się Kościół Etiopski w Jerozolimie.

Problematykę związaną z chrześcijańską tradycją etiopską przybliżył uczestnikom konferencji dr Marcin Krawczuk z Wydziału Orientalistycznego Uniwersytetu Warszawskiego. W referacie zatytułowanym „Pisma Ojców Kościoła w literackiej spuściźnie Etiopskiego Kościoła Ortodoksyjnego" prelegent zaznaczył, że literatura etiopska w języku gə‘əz stanowi objętościowo jedną z największych literatur chrześcijaństwa wschodniego. Znaczną jej część stanowią przekłady, wśród nich również tłumaczenia pism Ojców Kościoła. Przekładów tych dokonywano zarówno z greki, jak i z języka arabskiego, następnie zaś były one poddawane wielokrotnym rewizjom. Prelegent zauważył, że pisma patrystyczne nigdy nie były traktowane priorytetowo przez badaczy literatury etiopskiej, w odróżnieniu od apokryfów starotestamentalnych czy dzieł kanoniczno-liturgicznych, a przede wszystkim od utworów oryginalnych, a to natomiast oznacza to, że większość etiopskich tłumaczeń pism Ojców Kościoła pozostaje do dzisiaj w rękopisach.

Ksiądz dr hab. Jan W. Żelazny z Uniwersytetu Papieskiego Jana Pawła II w Krakowie przedłożył referat „Biblioteka jednego patriarchy”. Prelegent nawiązał w nim do jednego z bardziej znaczących zwierzchników Asyryjskiego Kościoła Wschodu, jakim był Tymoteusz I, patriarcha w latach 780-823. W historii swego Kościoła zapisał się jako teolog, polityk i wizjoner. Prelegent zwrócił uwagę, że w zachowanej spuściźnie patriarchy Tymoteusza, ważną pozycję stanowią listy, jednak zachowana korespondencja obejmuje sobą jedynie część panowania patriarchy. Ten fragmentaryczny rys pozwala na oszacowanie wielkości księgozbioru, jego bogactwa i rzuca światło na kulturę i wykształcenie środowiska, w którym żył i pracował Tymoteusz. Jednocześnie, jak zauważył ks. prof. Żelazny, pozwala to na porównanie i dostrzeżenie skali rozwoju tych wspólnot chrześcijan orientalnych w czasach, które w Europie Zachodniej nazywamy wczesnym średniowieczem.

Ostatni referat konferencji wygłosił ks. dr Michał Sadowski z Wydziału Teologicznego Uniwersytetu Mikołaja Kopernika w Toruniu. Wystąpienie zatytułowane „Nauka o Trójcy Świętej według MS Sinai Ar. 154” dotyczyło treści trynitarnych zawartych w najstarszym znanym chrześcijańskim tekście sporządzonym w języku arabskim. Prelegent zwrócił 
uwagę na bardzo umiejętne korzystanie z treści biblijnych, jak i koranicznych, służących do argumentacji za zasadnością chrześcijańskiej wiary $\mathrm{w}$ trójosobowego Boga.

Słowa podsumowania oraz podziękowania prelegentom i uczestnikom międzynarodowej konferencji naukowej wygłosił jej organizator, ks. prof. dr hab. Dariusz Zagórski. 